\title{
Světlo a život
}

Petra Caltová, Ivo Macek

$\mathrm{V}$ ýstava Světlo a život představila návštěvníkům Národního muzea život na Zemi v jeho nejrozmanitějších formách přizpůsobených na (ne)dostatek světla. Toho dosáhl autorský tým díky spolupráci širokého týmu z řad muzejních i externích spolupracovníků rozličných oborů, použitím moderních výstavních způsobů a muzejně-pedagogických metod.

\section{Prostorové řešení a instalace výstavy}

Výstava instalovaná v Nové budově Národního muzea představila návštěvníkưm klíčovou roli slunečního záření pro organismy v různých biotopech. Výstavní prostor se skládal ze čtyř tematických částí, které prezentovaly biotopy s rozdílnými světelnými podmínkami. Z tmavých jeskyní a půdních povrchů pokračovalo architektonické řešení přes travnaté oblasti až do přesvětlených korun tropického pralesa.

Vstupem do výstavy se návštěvníci ocitli uvnitř jeskyně, kde žijí organismy přizpů- sobené na nedostatek světla. Kde živočichové postrádají pigment, mají zakrnělé oči a $\mathrm{k}$ orientaci využívají především hmat. Cílem bylo vzbudit silný vstupní prožitek, který byl umocněn relativně úzkými prostory a minimálním osvětlením. Dominantou jeskynních prostor byla vitrína s exponáty a modely macaráta jeskynního, přezdívaného lidská ryba právě kvưli růžové kủži bez pigmentu.

Následující prostor se věnoval přechodu mezi světlem a tmou, organismům žijícím $\mathrm{v}$ půdě. Těm, které těsně pod povrchem hledají potravu i útočiště. Výrazným architektonickým prvkem byl kvádrový model řezu půdou s ukázkou čtyř živočichů a jejich nor.

V dalším sále návštěvníci vstoupili do otevřeného světlého prostředí stepí a savan. Biotopů, kde mají rostliny dostatek slunečního záření, a mohou tak naplno využívat schopnost fotosyntézy. Pro drobnější živočichy je životně důležitá hra světel a stínů, která jim v travnatém terénu pomáhá zůstat neviditelnými. Tento fenomén prezentoval model bukače pečlivě schovaný $\mathrm{v}$ rákosí v dioramatu mokřadi̊.

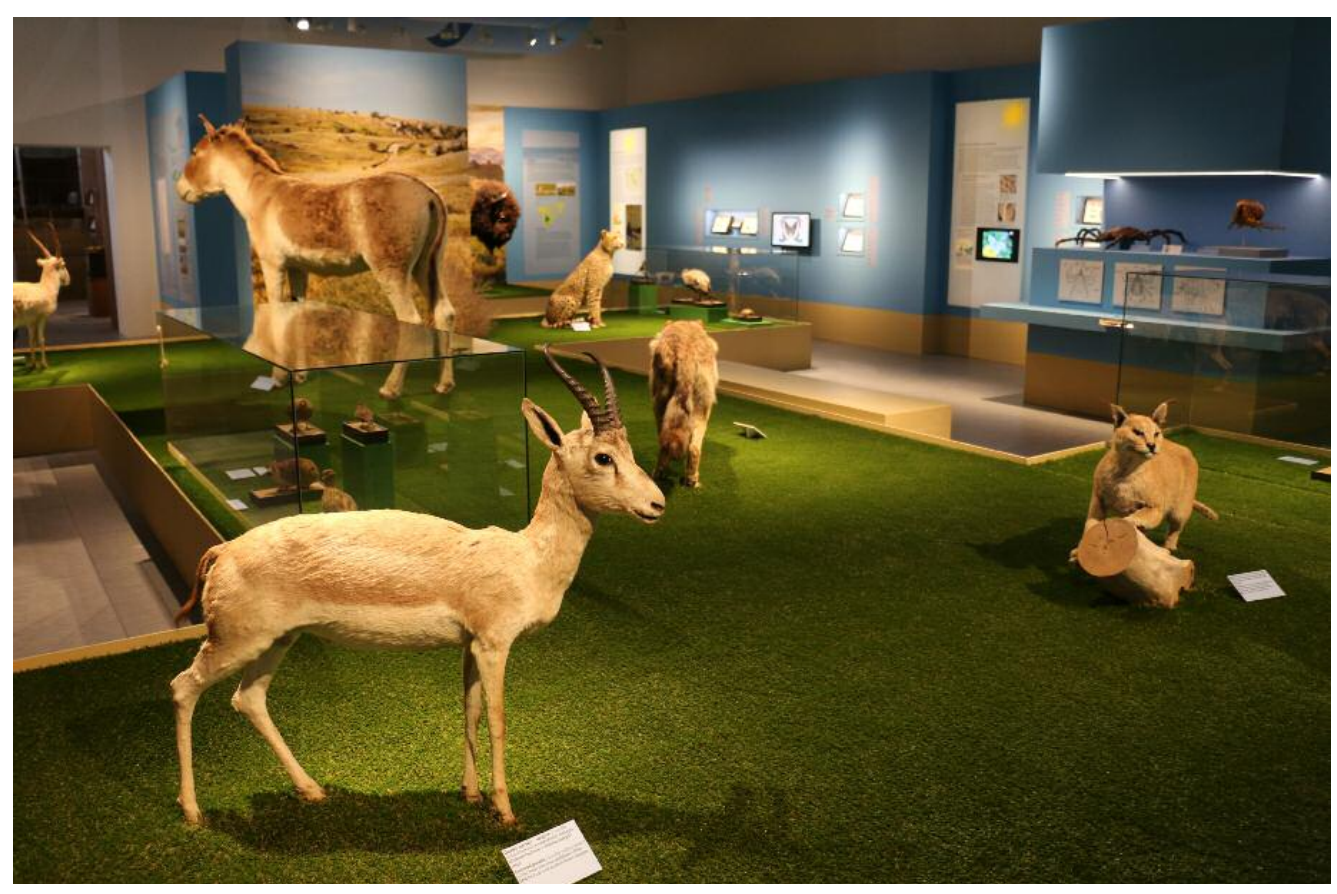

Obr. 1 Účelem architektonického řešení části stepí bylo vytvoření pocitu volnosti v kontrastu se stísněnými prostory první části výstavy.
Ing. Petra Caltová Prírodovědecké muzeum Národního muzea petra_caltova@nm.cz

Ing. RNDr. Ivo Macek ředitel Přírodovědeckého muzea Národního muzea ivo_macek@nm.cz 


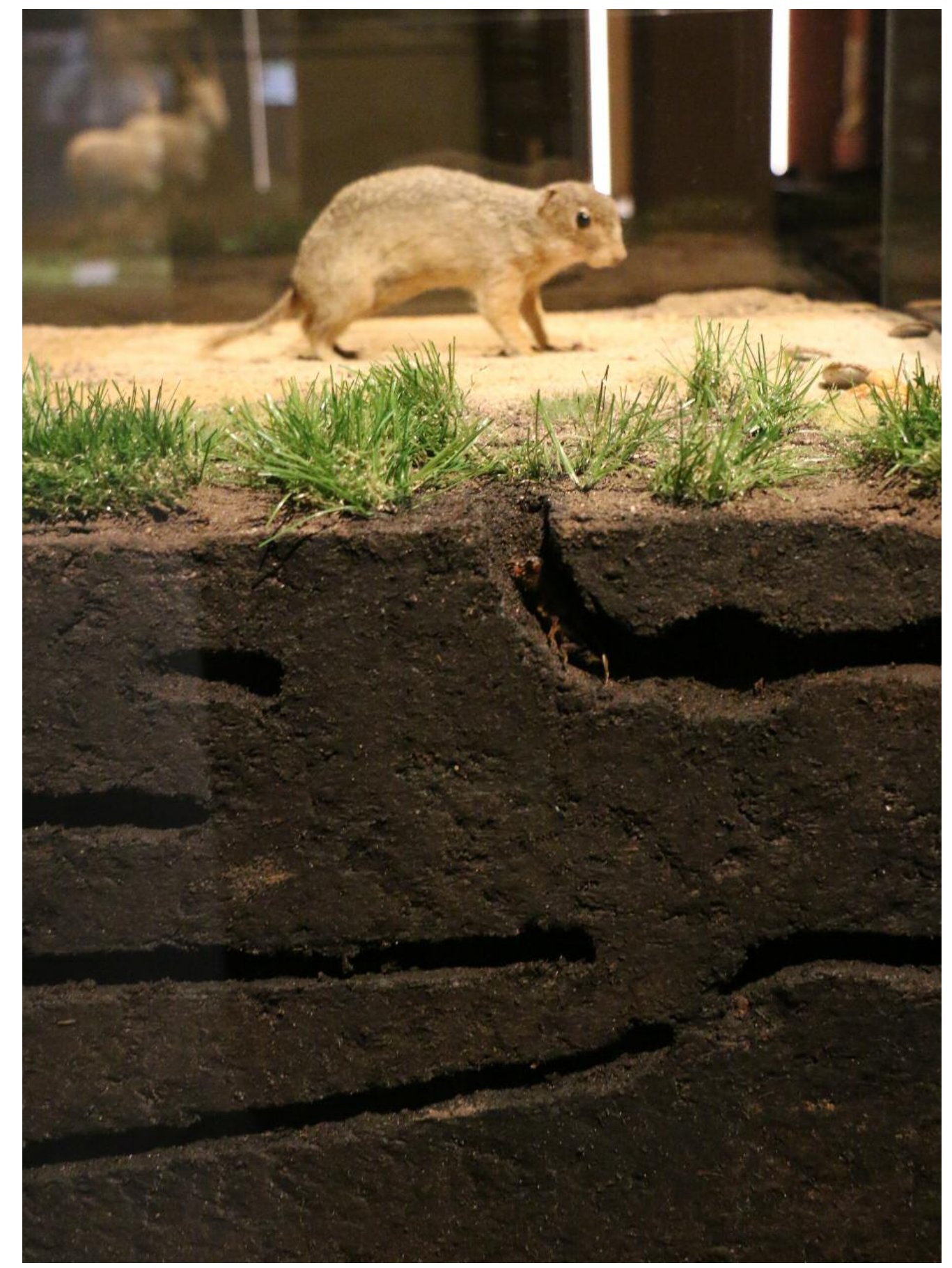

Obr. 2 Model řezu půdou s ukázkami různých typů nor. Na obr. nora krtonožky, v pozadí sysel obecný.

Na závěr výstavy se návštěvníci ocitli $\mathrm{v}$ tmavém tropickém pralese. Vitríny byly umístěny stupňovitě: spodní část představovala spodní patro pralesa, kde rostliny bojují o každý paprsek světla. Některé z nich dokonce postrádají chlorofyl, neprobíhá u nich fotosyntéza a živiny získávají parazitickým způsobem života. Ve výše umístěných vitrínách mohli návštěvníci spatřit organismy žijící ve vyšších patrech, 


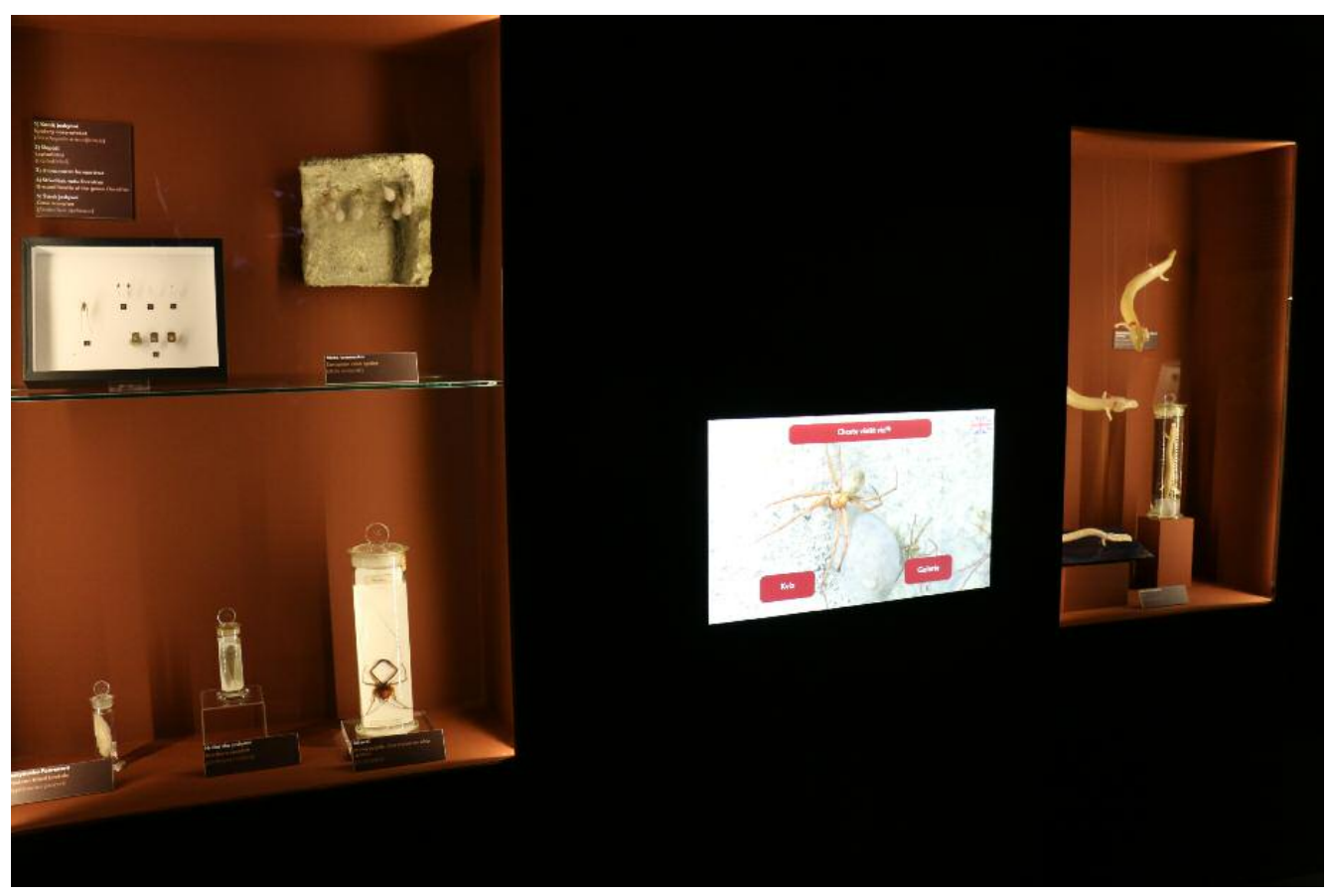

Obr. 3 Součástí interaktivní linky byly dotykové obrazovky, které návštěvníkưm hravou formou představily hlavní témata vitríny. Na obr. rưst hub v prostredí bez světla.

až v korunách stromů. Zde se rostliny naopak brání odparu způsobenému nadměrným množstvím slunečního záření. Místnosti dominoval model tropického stromu porostlý mechem a orchidejemi, v jehož vykotlané dutině byla umístěna skrytá vitrína s exponátem sklípkana.

Více než 250 vystavených sbírkových předmětů bylo do Nové budovy převezeno z depozitářů Př́rodovědeckého muzea v Horních Počernicích. Některé z exponátů se stěhovaly obtížně. Například entomologické sbírky jsou křehké a vyžadují citlivé zacházení. Jiné předměty jako např. dermoplastický preparát bizona bylo potřeba kvưli jeho rozměrům do výstavy ve druhém patře vynést po schodech, což zajistilo šest pracovníků stěhovací firmy.

\section{Unikátní výstavní projekt}

Národní muzeum v rámci všech svých objektů zpřístupňuje návštěvníkům ročně desítky výstav s různorodými tématy. Ve většině případi̊ se však jedná o jednoobo- rové výstavy s humanitním nebo přírodovědným zaměřením.

I když byla výstava Světlo a život především přírodovědně zaměřená, představila roli světla nejen $\mathrm{v}$ prrírodě, ale i v lidském životě. Díky tomuto prưřezovému tématu se na př́ipravě výstavy podíleli také odborní pracovníci Historického muzea, kteří návštěvníkům přiblížili úlohu ohně ve vývoji lidské kultury. Koncept výstavy zahrnoval také představení fyziologických procesů ovlivněných světlem nebo principy moderních technologií inspirovaných světelnými jevy (např. mikrostruktura motýlích křídel byla základem výroby LCD obrazovek). Na těchto tématech spolupracovali odborníci z Př́rodovědecké fakulty Univerzity Karlovy.

\section{Muzeum hravě}

Jednotlivá témata výstavy byla představena nejen pomocí sbírkových předmětů s doprovodnými texty, ale také prostřednictvím interaktivní linky. Autoři se rozhodli představit hlavní témata výstavy 


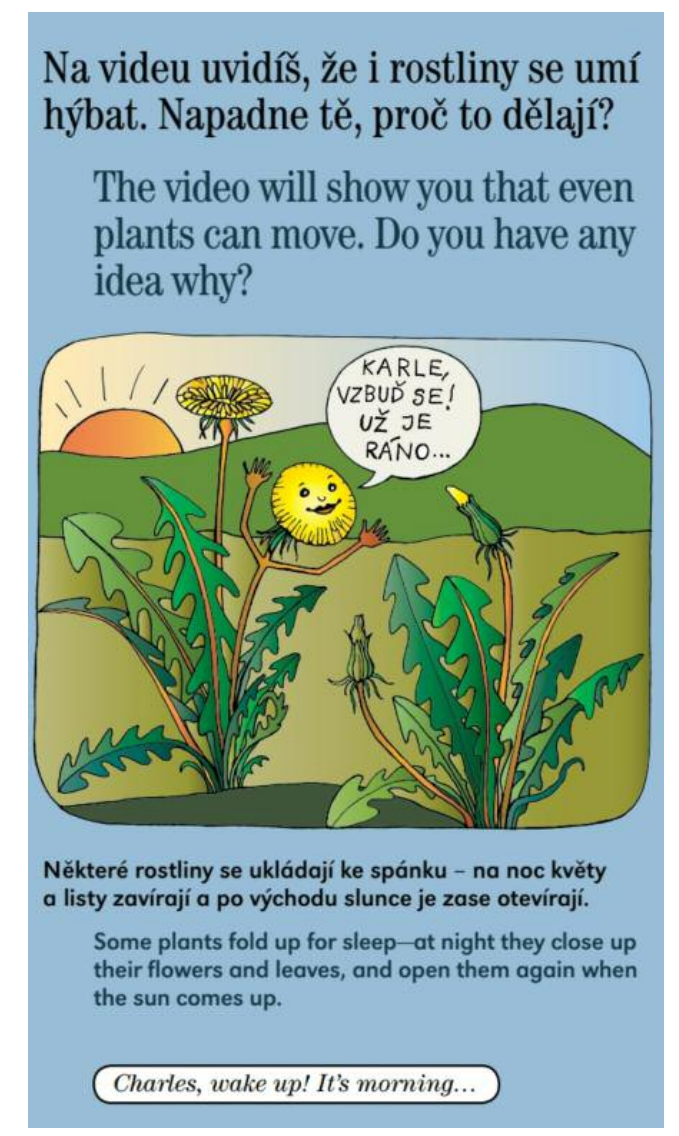

Obr. 4 Komiks vysvětlující pohyby rostlin $v$ závislosti na intenzitě dopadajícího světla.

hravou formou nejen dětem, ale návštěvníkům všech věkových kategorií. To se podařilo mimo jiné využitím různorodých typů aktivit na dotykových obrazovkách. Kromě hlubší informace o okolních sbírkových předmětech a jejich velkoformátových fotografií zde návštěvníci našli krátké hry týkající se představovaného tématu. Jejich absolvováním získávali písmena hádanky a mohli se tak každý měsíc zúčastnit soutěže o ceny. Součástí interaktivní linky byly také haptické přírodniny a jednoduché mechanické aktivity, které kromě rozvoje drobné motoriky u dětských návštěvníků podporovaly mezigenerační rozhovor při jejich společném řešení. Základní fenomény týkající se hlavních témat výstavy byly dětskému návštěvníkovi podávány formou jednoduchých vtipných komiksů.

Jako doprovodná publikace $\mathrm{k}$ výstavě vznikl katalog, který obsahoval výběr textů o vlivu (ne)dostatku světla na život. Každou kapitolu uzavřela hravá dvoustrana, kde si nejen dětští návštěvníci pomocí krátkých aktivit zopakovali, co vše je ve výstavě zaujalo.

Celkem si Světlo a život prohlédlo více než 100000 návštěvníků. Vzhledem k tematické návaznosti na rámcové vzdělávací programy zařadili do výuky účast na doprovodných programech pedagogové s 240 školními skupinami. Způsoby podání oborového obsahu ve výstavě jsou zmíněny $\mathrm{v}$ publikaci Muzejní edukátor. ${ }^{1}$
1 Šobáňová, Petra. Komponenty muzejní edukace - cíle, obsahy, metody, formy, prostredky. In Kolektiv autorů. Muzejní edukátor. Studijní materiál [online]. Moravské zemské muzeum, 2019 [cit. 6. 11. 2019]. Dostupné z: http://www.mcmp.cz/fileadmin/user_upload/vzdelavani/ST UDIJNI_MATERIAL_2019.pdf

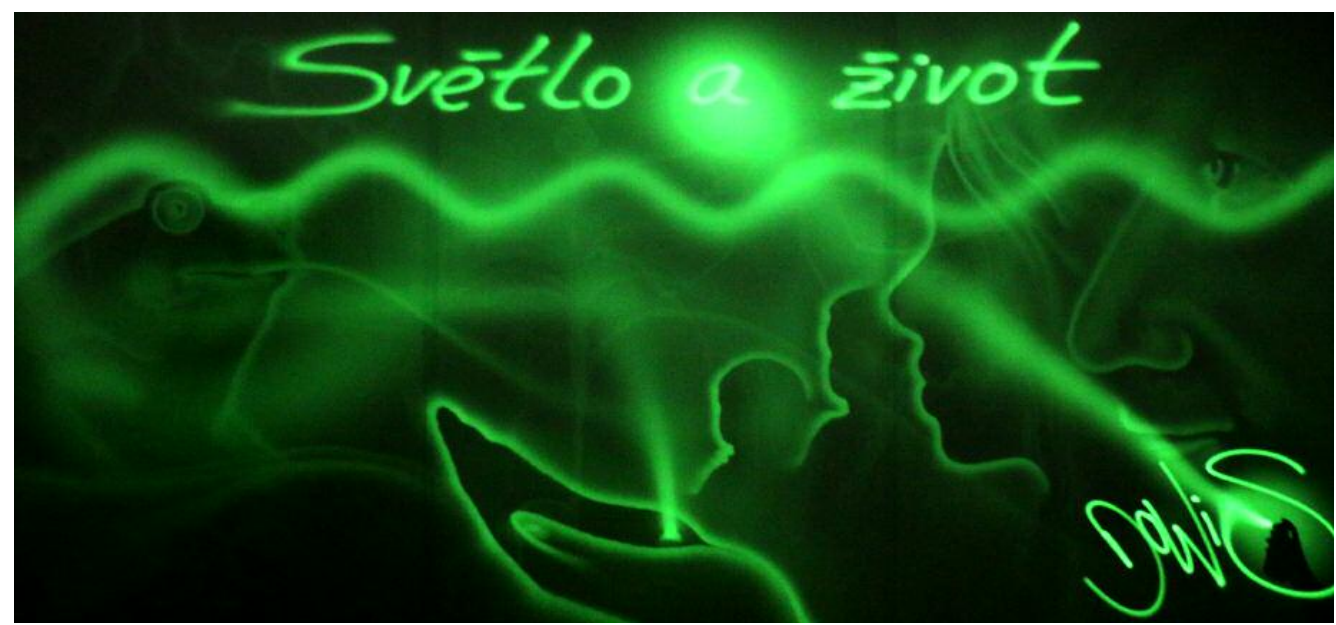

Obr. 5 Ve výstavě si návštěvníci mohli vyzkoušet malování světlem. 
Na základě zapojení Národního muzea do projektu MŠMT Pokusné ověřování „,Vzdělávací programy pamětových institucí do škol" proběhla ve výstavě hospitace výukového programu zaměřená na možnosti užší spolupráce škol a pamětových institucí ve výuce humanitních a prírodovědných oborů.

Kromě klasických komentovaných prohlídek a výukových programů probíhaly $\mathrm{v}$ rámci doprovodných akcí $\mathrm{k}$ výstavě také návštěvnicky vděčné pokusy na pomezí fyziky a biologie - např. lom paprsků světla na vodní hladině, barevné spektrum světla na ptačím peří a křídlech motýlů nebo mezidruhový rozdíl ve vnímání ultrafialového a infračerveného světla.

\section{Sbírkové předměty}

Exponáty ve výstavě pocházely z oddělení napřič Př́írodovědeckým muzeem. Vystaveny byly minerály, které fluoreskují pod UV světlem, zoologické, botanické i mykologické sbírkové předměty, které se různou měrou přizpůsobují (ne)dostatku

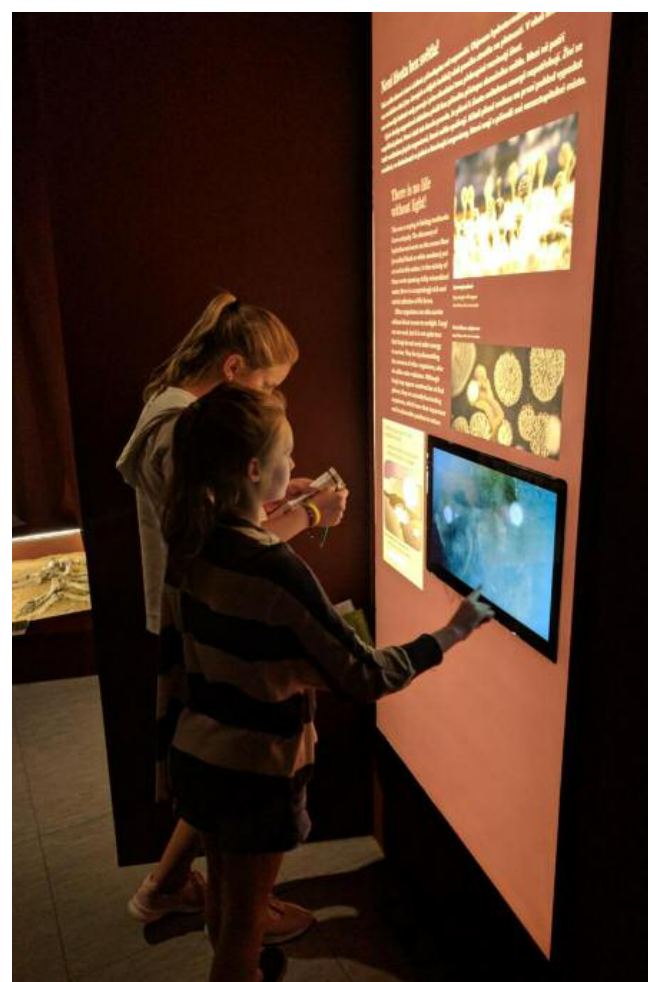

Obr. 6. Z dotykových obrazovek se návštěvníci dozvěděli hlubši informace o vystavených sbírkových předmětech.

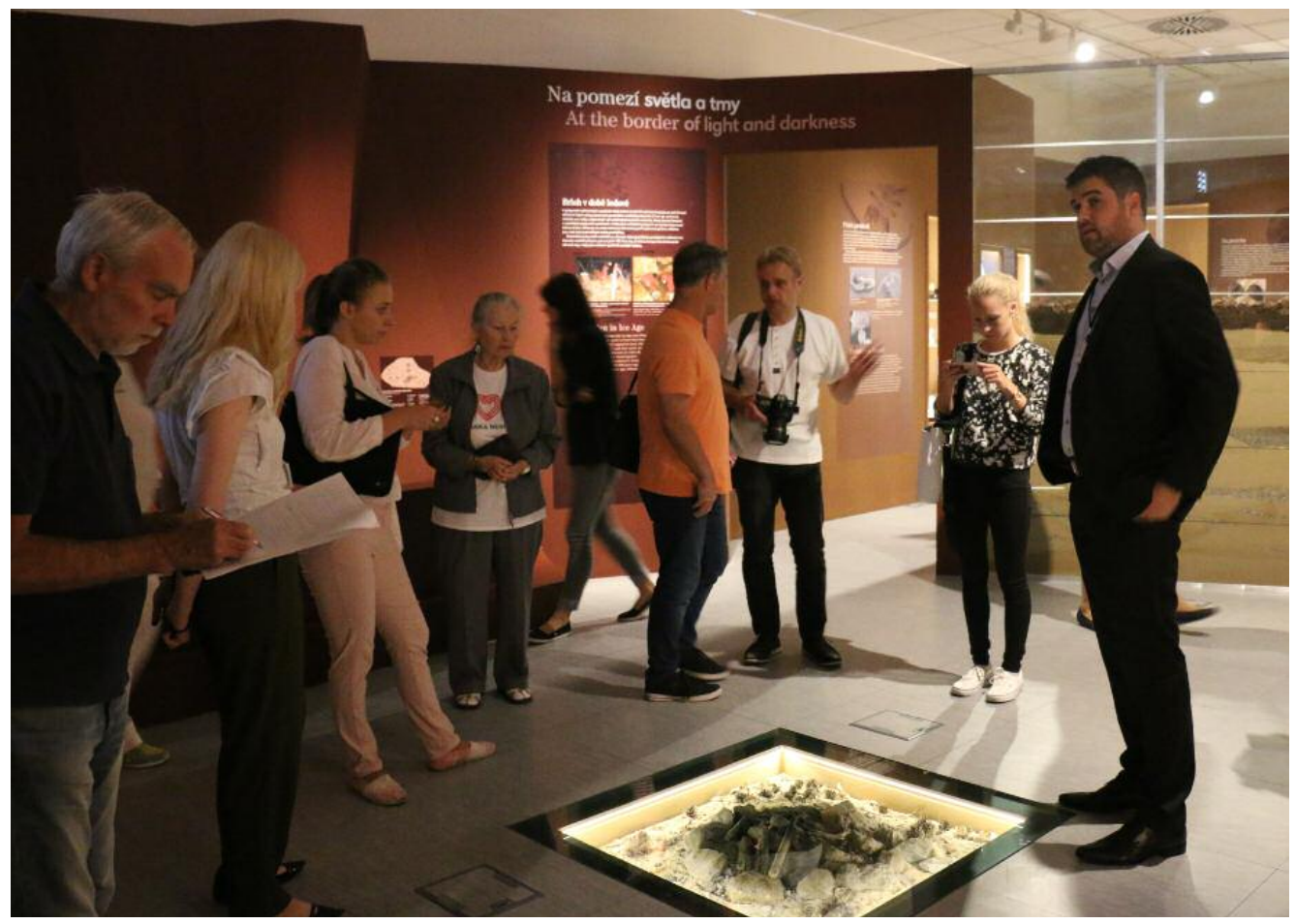

Obr. 7 Působení člověka v okolí jeskyní představovala pochozí vitrína s modelem ohniště. 


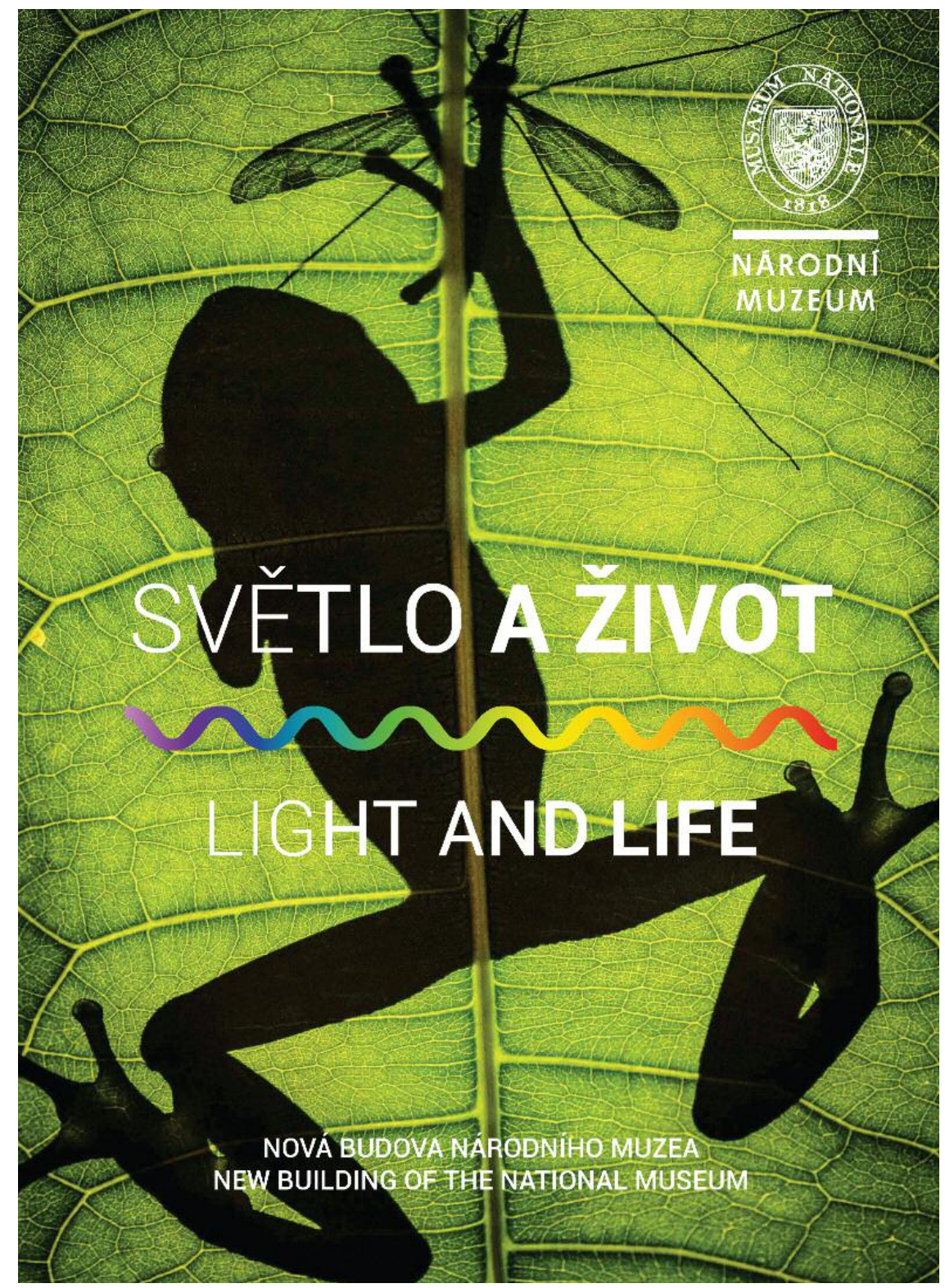

Obr. 8 Průvodce výstavou Světlo a život přední strana obálky. světla. Návštěvníci si mohli prohlédnout i pozůstatky z dob, kdy lidé využívali jako útočiště jeskyně, podobně jako např. hyena jeskynní, jejíž kostra byla také vystavena.

Některé exponáty ve výstavě patřily k historickým unikátům, jako např. karakal, kterého do sbírek Národního muzea získal na svých cestách český cestovatel a etnograf Emil Holub. Cást dermoplastických preparátů prošla rukama restaurátorů Zoologického oddělení Národního muzea.

Jiné předměty, především modely, byly vyráběny do nových př́rodovědných expozic, které se budou realizovat v Historické budově. Ve výstavě Světlo a život tedy měly svou premiéru. Jednalo se např. o modely macaráta jeskynního nebo ně- kolikanásobně zvětšené modely blechy a klíštěte.

\section{Závěr}

Výstava Světlo a život je ukázkou spolupráce pracovníků např́č složkami Národního muzea, ale zároveň kooperace s externími odborníky. Autorský tým při přípravě postupoval podle trendů moderního výstavnictví, které kladou důraz na prožitek návštěvníka. Toho bylo docíleno jak zajímavým architektonickým ztvárněním, tak představením vybraných sbírkových předmětů a interaktivní linkou. Tvorbou tohoto výstavního projektu získal autorský tým množství cenných informací a podnětů o funkčnosti různých metod používaných v moderním výstavnictví. Tyto zkušenosti budou využity při přípravách nových přírodovědeckých expozic v Historické budově Národního muzea.

\section{Použité zdroje}

ŠOBÁŇOVÁ, Petra. Expozice jako místo vzdělávání. Metodika k tvorbě expozic zohledňující vzdělávací potřeby návštěvníků. Brno: Moravské zemské muzeum, 2017. ISBN 978-80-7028-494-0.

ŠOBÁŇOVÁ, Petra. Komponenty muzejní edukace - cíle, obsahy, metody, formy, prostředky. In Kolektiv autorů. Muzejní edukátor. Studijní materiál [online]. Moravské zemské muzeum, 2019 [cit. 6. 11. 2019]. Dostupné z: http://www.mcmp.cz/fileadmin/user _upload/vzdelavani/STUDIJNI_MATERIAL_2019.pdf

TOMEŠKOVÁ, Kateřina. Když jsme se o tom ve škole učili, tak jsem to neviděl ve 3D... [online]. Národní pedagogické muzeum a knihovna J. A. Komenského, 2019 [cit. 6. 11. 2019]. Dostupné z: https:/ / www.npmk.cz/pro-skoly/pokusne-overovani/neformalni-hospitace-prubezne-zpravy/kdyz-jsme-se-otom-ve-skole-ucili 